\title{
Effect of Prolonged Irrigated Fodders on Soil Physical Properties and Agronomic Water Use Efficiency
}

\author{
Zahid Murtaza ${ }^{1, *}$, Waqas Ahmad ${ }^{2}, J^{\prime}$ il Shafi ${ }^{3}$, Muhammad Shoaib ${ }^{1}$, Muhammad Aqeel Sarwar ${ }^{4}$, \\ Muhammad Asif Shehzad ${ }^{4}$ \\ ${ }^{1}$ Institute of Soil and Environmental Sciences, University of Agriculture, Faisalabad (38040) Pakistan \\ ${ }^{2}$ Institute of Horticultural Sciences, University of Agriculture, Faisalabad (38040) Pakistan \\ ${ }^{3}$ Department of Plant Pathology, University of Agriculture Faisalabad (38040) Pakistan \\ ${ }^{4}$ Department of Agronomy, University of Agriculture Faisalabad (38040) Pakistan \\ *Corresponding Author: uaf3840@gmail.com
}

Copyright (C) 2013 Horizon Research Publishing All rights reserved.

\begin{abstract}
The experiment was conducted to evaluate the effect of prolonged irrigated fodders on soil key parameters and agronomic water use efficiency. The experiment was laid-out in Randomized Complete Block design with split plot arrangement having four replications with a net subplot size of $7 \mathrm{~m} \times 3 \mathrm{~m}$. Treatments consisted of two crops (pearl millet and sorghum) and three irrigation levels (2, 3 and 4 numbers of irrigation). Soil parameters, i.e. organic carbon, particle density, bulk density, porosity were measured at three depth, i.e. $0-5 \mathrm{~cm}, 5-10$ and $10-15 \mathrm{~cm}$. Agronomic parameters were also recorded such as plant height, fresh biomass and dry biomass. The results of this study showed that the maximum fresh biomass of sorghum (27.96 Mg ha-1) and of pearl millet (28.16 Mg ha-1) was observed with treatment where three number of irrigation was applied. The maximum agronomic water use efficiency was also observed with three number of irrigation in both the crops. The minimum soil bulk density and maximum percentage of pore spaces was observed with I 2 where three number of irrigation was used in case of pearl millet and sorghum.
\end{abstract}

Keywords Prolonged Irrigation, Soil Parameters, Pearl Millet,Sorghum

\section{Introduction}

Fodders are the very vital resource for the development of agricultural economy of the poor countries for the purpose of livestock raising. In Pakistan, Punjab is the leading province in fodder production area with 2.7 million hectares. The annual production of fodders in the province is 57 million tones with 21.1 tons ha ${ }^{-1}$ average fodder yield $[1,2]$.

Among the kharif forage crops, sorghum (Sorghum bicolor $\mathrm{L}$.) is an important one that possesses a wide range of ecological adaptability because of its xerophytic properties.
Sorghum is usually grown by all the farmers in the rainfed and irrigated area of Pakistan. Its forage is fed to every type of livestock and can be used as hay or silage. Sorghum fodder is poor in quality due to low protein content and presence of hydrocyanic acid [3]. Among the many options to overcome the shortage of forage, the best one is the introduction of high yielding crop varieties [2].

Pearl millet is an important fodder crop of Pakistan. Millet is a summer annual forage crop consumed as a food as well as a fodder for livestock in the world and one of the most important kharif fodder in Pakistan. In developed countries like Australia and USA, pearl millet is used as a high quality forage crop and in South America and Korea it is likely to be experimented as a forage crop [4]. In Pakistan at least $50 \%$ of the irrigated and $25 \%$ of the rain fed millet area is harvested exclusively for animal feed purpose before the formation of grains. In Pakistan pearl millet faces yield reduction problems due to less research on the variety improvement. Under arid conditions with very low water availability, pearl millet shows high fodder production. Its performance is excellent under dry land cultivation due to its resistance to water stress. Different cultivars show different yield potential and growth habits [5-10]. There is a dire need to develop high green fodder yielding pearl millet varieties to increase fodder production in Pakistan. Millet is grown in the season of Zaid kharif when monsoon season starts. In Pakistan the pearl millet fodder occupies an area of 438,000 hectares with an average production of 221,000 tones of grains. The grain yield of the pearl millet is 508 tons $\mathrm{ha}^{-1}$ [11].

Soil physical conditions are very important for proper plant growth. These properties depend on each other and are interrelated [12]. Bulk density is a measure of the mass of the soil per unit volume of soil including pore-spaces. Variation in bulk density is attributable to the relative compactness of solid organic and inorganic particles and to the porosity of the soil. Bulk density is important for comparing 
management practices of cultivated soil versus uncultivated soils [13].

Agricultural land becomes hard, difficult for the tillage operations and decreases their aggregate stability due to the trafficking [14] and heavy machinery causes the compaction of the soil increasing the soil strength [15].The mechanical strength of the soil decreased the soil productivity due to poor seedling emergence [16]. Soil strength is measure of resistance offered by the soil to penetration and it determines the ability of crop plants in terms of seed germination and resistance to root development [17].

Water use efficiency of crop is the mass $(\mathrm{kg})$ of the dry matter produced per unit mass of water consumed or transpired. The water use efficiency of the crops can be improved by the management of the soil and agronomic strategies of the crops [18]. The most important factor for growth and development of plants is the water contents of the soil [19]. The main factor that causes the restoration of the soil water is the rain water harvest [20].

Water stress causes the reduction in yield of fodders in the arid to semi-arid regions of the world. Low availability of water produced the problems of water stress [21]. The shortage of fresh water has forced the land owners to use the available low quality brackish irrigation water for their livestock and crop production [22]. Due to the use of this water source the crop productivity increased to some extent and drought conditions were minimized but the soil salinity problems increased [23].

The management of water, crop and soil can be made effective by increasing root penetration and improving water use efficiency or photosynthetic capacity [24].. This adaptation remains effective until stress conditions are severe or prolonged [25, 26]. Sustainable agricultural management practices are known to influence soil physical properties to maintain functional capacity of soil for crop growth [27, 28].

Keeping above facts in view, the study was carried-out to evaluate the effect of irrigated fodders on soil physical properties, water use efficiency and yield of pearl millet and sorghum.

\section{Materials and Methods}

The experiment was conducted to evaluate the effect of fodders on soil physical properties and agronomic water use efficiency under the field conditions at Government Livestock Farm Jugait-Peer Bahawalpur, Cholistan.

The experiment was carried-out by following Randomized Completely Block Design (RCBD) having split plot arrangements. Two crops were used in study and were grown in the main plots and the number of irrigations $\left(\mathrm{I}_{1}, \mathrm{I}_{2}, \mathrm{I}_{3}\right)$ were applied in the subplots. Each treatment was repeated for four times. The net plot size was $7 \mathrm{~m} \times 3 \mathrm{~m}$ for each treatment.

\section{Factor A: Crops}

Sorghum (Sorghum bicolor L.)

Pearl millet (Pennisutum americanum L.)
Factor B: irrigation levels (No. of Irrigations)

$\mathrm{I}_{1}$ (Four number of irrigations)

$\mathrm{I}_{2}$ (Three number of Irrigations)

$\mathrm{I}_{3}$ (Two number of Irrigations)

Total number of experimental units became 24. Two crops were grown in mid July by broadcast method at wattar condition. Recommended doses of fertilizers (80:60:0 and 75:60:0 N, P, K) for sorghum and pearl millet were applied. All phosphatic fertilizer was applied at sowing time with $1 / 3$ of nitrogen while the remaining dose of nitrogen was applied with irrigations. Diammonium phosphate was used as the source of phosporus and for nitrogen urea was used. The harvesting of crops was done after 3 months in mid October. All the plant parameters were measured and for laboratory analysis samples were collected.

All plant protection measures were taken during the growth periods from germination to maturity. Pesticides were sprayed for the control of stem borers. Canal water was used for irrigation purposes with the help of electric turbines.

\subsection{Crop Parameters (Agronomic Parameters)}

Agronomic parameters like plant forage yield, dry matter yield, plant height, plant population, number of leaves per plant and leaf area were determined in the field as well as in the laboratory. The following procedures were adopted for collection of data on the above mentioned parameters in growing seasons.

\subsubsection{Plant height $(\mathrm{cm})$}

The plant height of ten randomly selected plants from each plot was measured from base to the highest leaf tip with the help of a measuring tape and then their average was worked out.

\subsubsection{Plant population $\left(\mathrm{m}^{-2}\right)$}

The plant population was recorded by counting the all plants in one square meter at three randomly selected places in each plot of each replication and then the average was calculated.

\subsubsection{Number of leaves per plant}

Total numbers of leaves of ten randomly selected plants were counted from each replication and then the average number of leaves per plant was calculated.

\subsubsection{Fresh leaves weight $(\mathrm{g})$}

The leaves of the plants harvested from each replication were weighed on the balance to get their fresh leaf weight.

\subsubsection{Leaf area $\left(\mathrm{m}^{-2}\right)$}

Plants were harvested from one sequre meter area then all the leaves of the harvested plants from each replication were removed and their weight was recorded separately, sub-sample (10 g) of green leaf laminae was used to record leaf area by using Li-Cor 3100 leaf area meter (LI-COR Inc. Lincoln, NE). 


\subsubsection{Dry leaves weight (g)}

The leaves of the plants harvested from each replication were oven dried at $65{ }^{\circ} \mathrm{C}$ till constant weight to get the dry weight of the leaves and the samples were weighed on the balance.

\subsubsection{Water contents in the leaves / stem}

Water contents in the leaves were measured by using the values of fresh leaf weight and dry leaf weight with the help of formula:

$$
\text { Water use efficiency }=\frac{\text { Yield } \mathrm{kg} \mathrm{ha}^{-1}}{\text { Water applied }(\mathrm{mm})} \times 100
$$

2.1.8. Stem fresh weight $\mathrm{m}^{-2}(\mathrm{~g})$

Total weight of ten randomly selected stem were measured on the analytical balance and then the average weight of stem per plant was calculated.

\subsubsection{Stem dry weight $\mathrm{m}^{-2}(\mathrm{~g})$}

The samples were oven dried at $65^{\circ} \mathrm{C}$ till constant weight and weighed on the balance.

\subsubsection{Fresh forage yield $\left(\mathrm{Mg} \mathrm{ha}^{-1}\right)$}

The plants from one meter square were harvested to record fresh weight of forage from each plot. The harvested sample was weighed with the help of an electric balance and fresh weight was calculated.

\subsubsection{Dry matter yield $\left(\mathrm{Mg} \mathrm{ha}^{-1}\right)$}

For calculating dry weight of forages, harvested plants from one meter square of each plot were chopped into small pieces with the help of a manual fodder cutter. The chopped plant material was mixed thoroughly and then a representative sample of $500 \mathrm{~g}$ was taken in muslin cloth bags and thereafter, dried in an oven at $65^{\circ} \mathrm{C}$ to a constant dry weight and then reweighed to calculate the dry weight of the sample.

\subsubsection{Water use efficiency $\left(\mathrm{Kg} \mathrm{ha}^{-1} \mathrm{~mm}^{-1}\right)$}

The water use efficiency of the fodders was calculated by following formula:

$$
\text { Water content in leaves,stem }=\frac{\text { Fresh sample wt.-dry sample wt. }}{\text { Fresh sample wt. }} \times 100
$$

\subsection{Soil Physical Properties}

Soil samples were collected for the determination of soil bulk density, soil particle density. The samples for bulk density were collected by core method. The porosity of the soil was determined using the values of bulk density and particle density. The soil strength parameter was determined by using cone penetrometer.

For determination of soil physical properties like soil texture, hydrometer method was used [29]. Texural classes of soil were determined by following International System Textural Triangle. Soil physical parameters were measured before sowing and after harvesting of the crop.

Bulk density was measured by Blake and Hartge [30]. method. Samples for bulk density $\left(\rho_{h}\right)$ were taken at three depth levels $\left(D_{1}, D_{2}, D_{3}\right)$, i.e. at 5,10 and $15 \mathrm{~cm}$, respectively

\subsubsection{Soil Texture}

\subsubsection{Dispersing solution}

One percent sodium hexametaphosphate and sodium carbonate solution was prepared. Took 40 grams of sodium hexametaphosphate and 10 grams of sodium carbonate in $1000 \mathrm{~mL}$ volumetric flask. The salts were weighed on digital electric balance to avoid the error in weight. The volume was made up to the mark with deionized water.

Forty grams of oven dried soil was weighed on the weighing balance and poured in the $500 \mathrm{~mL}$ plastic beaker. Added $60 \mathrm{~mL}$ of dispersion solution in the soil and also added $150 \mathrm{~mL}$ of distill water. Covered the sample with watch glass and placed for overnight. Transferred the soil quantitatively in the stirring cup and filled cup up to three quarter with distill water. Ran the stirrer for three minutes. Transferred the solution in the hydrometer jar. Cleanly run the stirrer paddle in the jar and placed solution for one minute. Brought the volume with water up to the mark.

\subsubsection{Determination of blank}

Took $60 \mathrm{~mL}$ of the dispersing solution in $1000 \mathrm{~mL}$ hydrometer jar and made the volume with distill water. After mixing the solution took the hydrometer reading for blank $\left(\mathrm{R}_{\mathrm{b}}\right)$. The temperature of the blank solution was measured for correction. Hydrometer procedure protocol needs temperature of $20{ }^{0} \mathrm{C}$. The rise or fall in temperature is adjusted with a factor 0.4 for each degree centigrade.

\subsubsection{Determination of $\%$ silt + clay}

Soil solution from the stirrer was transferred in the hydrometer jar and inserted plunger to well mix the solution. After 40 seconds took the hydrometer reading fo silt + clay $\left(\mathrm{R}_{\mathrm{sc}}\right)$. Temperature of the solution was measured for the temperature correction purpose.

$\%$ Silt + Clay $=\left(\mathrm{R}_{\mathrm{sc}}-\mathrm{R}_{\mathrm{b})} \times 100 /\right.$ (oven dry weight of soil)

\subsubsection{Determination of $\%$ clay}

After 4 hours, took the reading for $\%$ clay $\left(R_{c}\right)$ with hydrometer and took the temperature correction reading.

$$
\% \text { Clay }=\left(R_{c}-R_{b}\right) \times 100 /(\text { oven dry weight of soil) }
$$

\subsubsection{Determination of $\%$ silt}

Percentage silt was determined by the following formulae:

$$
\% \text { Silt }=(\% \text { Silt }+ \text { Clay })-(\% \text { Clay })
$$

\subsubsection{Determination of $\%$ sand}

Percentage sand was determined by the following 
formulae:

$$
\% \text { Sand }=100-(\% \text { Silt }+ \text { Clay })
$$

2.2.1.7. Soil texture analyses of the field

$$
\begin{gathered}
\text { Sand }=74.5 \% \text {, silt }=15.5 \% \text {, clay }=10 \% \\
\text { Textural class }=\text { Loamy sand }
\end{gathered}
$$

\subsubsection{Soil strength}

Soil strength was measured with Cone penetrometer. The penetrometer was operated by placing the core on the soil surface with the shaft oriented vertically. The cone was then pressed into the soil until it just becomes buried (i.e. soil surface was level with the base of cone). Then reading was noted. Soil sample for water content were also taken, and then correlated to force applied. Each plot was repeated three times [31].

\subsubsection{Determination of soil particle density}

For the measurement of soil volume for particle density I took $100 \mathrm{~mL}$ volumetric flasks and added 25 grams of soil in the flask. Then added $50 \mathrm{~mL}$ of distill water in the flask. Then placed the flasks for overnight. After 24 hours the flasks were capped with a cork having small glass tubes to allow the extrusion of air bubbles from the soil by heating the suspension on the hot plate. After removing the bubbles placed the caps on the flasks and then made the volume of flask up to the mark with dionized water.

Soil particle density data sheet was made and the soil mass and volume was determined (table 1).

\subsubsection{Soil Bulk Density}

The most common method for measuring volume of soil for soil bulk density is the core method [32]. Bulk density of the soil is determined with the help of core method. The samples for bulk density were collected by gently hammering the metallic core in the soil. Excavated the soil around the ring to take the full soil sample. Carefully poured the soil into the plastic zip lock bag, marked and sealed the bags without losing any soil [33].

$$
\text { Bulk density }\left(\mathrm{g} / \mathrm{cm}^{3}\right)=\frac{\text { Dry soil weight }(\mathrm{g})}{\text { Soil bulk volume }\left(\mathrm{cm}^{3}\right)} \times 100
$$

\subsubsection{Core volume}

The volume of the soil was determined by measuring the inner volume of the steel core containing the soil. Height of steel ring was determined by using the ruler in $\mathrm{cm}$ and then diameter was measured. Radius of the core was measured by dividing the diameter by a digit of two and the volume of core was determined by the formula:

$$
\text { Core volume }=3.14 \times \mathrm{r}^{2} \mathrm{x} \text { ring height }
$$

Where ' $r$ ' is radius of the core.

\subsubsection{Dry weight of soil (g)}

Weighed a steel container in grams $\left(\mathrm{W}_{1}\right)$ then poured the soil from bag in this container. The soil was dried at least for 24 hours at $105^{\circ} \mathrm{C}$. When the soil was oven dried, took the container with soil on balance and weighed it $\left(\mathrm{W}_{2}\right)$. The difference between two weights was the weight of oven dry soil.

$$
\text { Mass of oven dry soil }=\mathrm{W}_{2}-\mathrm{W}_{1}
$$

\subsubsection{Total porosity}

Total porosity of the soil was determined from the values of soil bulk density $\left(\rho_{h}\right)$ and particle density $\left(\rho_{n}\right)$ by the following formula:

$$
\text { Total porosity }=\left|1-\left(\rho_{h} / \rho_{n}\right)\right| \times 100
$$

\subsection{Statistical Analysis}

The data collected was statistically analyzed using Analysis of Variance technique. The means were compared by the least significant difference (LSD) test at $\alpha \leq 0.05$ [34].

Table 1. Soil particle density data sheet

\begin{tabular}{cc}
\hline Procedure & Readings \\
\hline Soil + flask weight $(\mathrm{g})$ & $=\mathrm{A}$ \\
Flask weight $(\mathrm{g})$ & $=\mathrm{B}$ \\
Soil weight $(\mathrm{g})=\mathrm{C}$ & $=\mathrm{D}-\mathrm{B})$ \\
Soil + flask + water weight $(\mathrm{g})$ & $=(\mathrm{D}-\mathrm{A})$ \\
Mass of water $(\mathrm{g})=\mathrm{E}$ & $=1$ \\
Density of water $\mathrm{g} / \mathrm{cm}^{3} \quad \mathrm{~F}$ & $=\mathrm{E} / \mathrm{F}$ \\
Volume of water $=\mathrm{G}\left(\mathrm{cm}^{3}\right)$ & $=100-\mathrm{G}$ \\
Volume of soil $=\mathrm{H}$ & $=\mathrm{C} / \mathrm{G}$ \\
Density of soil $=\mathrm{I}\left(\mathrm{g} \mathrm{cm}^{-3}\right)$ &
\end{tabular}

Oven dried mass of soil (g). 


\section{Results}

The experiment was conducted to evaluate the effect of fodders on soil physical properties and agronomic water use efficiency under field conditions at Government Livestock Farm Jugait-Peer Bahawalpur, Cholistan. Randomized Completely Block Design (RCBD) was followed having split plot arrangements. Two crops were used in this study and were grown in the main plots and the number of irrigations $\left(I_{1}, I_{2}, I_{3}\right)$ were applied in the subplots. Each treatment was repeated four times. The net plot size was $7 \mathrm{~m}$ $\times 3 \mathrm{~m}$ for each treatment. The findings of this study are discussed as under.

\subsection{Plant Height}

The maximum plant height of pearl millet was observed with treatment $I_{2}$ where three number of irrigation was applied and that was $246.3 \mathrm{~cm}$. It was followed by $\mathrm{I}_{3}(2$ number of irrigations) and $\mathrm{I}_{1}$ (4 number irrigations) that showed 231.3 and $236.3 \mathrm{~cm}$ plant height of pearl millet, respectively. Similar trend was observed in case of sorghum (Fig. 1a). The maximum plant height of sorghum was observed with treatment $\mathrm{I}_{2}$ where three number of irrigation was applied which was $215.63 \mathrm{~cm}$. It was followed by $\mathrm{I}_{1}(4$ number of irrigations) and $I_{3}$ (2 number irrigations) that showed 210.63 and $194.38 \mathrm{~cm}$ plant height of sorghum, respectively (Fig.1b).

\subsection{Number of Plants $\left(\mathrm{M}^{-2}\right)$}

It could be observed from Fig. 2a that the maximum number of plants $\left(\mathrm{m}^{-2}\right)$ of pearl millet was observed with treatment $\mathrm{I}_{2}$ where three number of irrigation was applied and that was 76 plants. It was followed by $\mathrm{I}_{1}$ (4 number of irrigations) and $\mathrm{I}_{3}$ (2 number irrigations) that showed 76 and 70 plants $\left(\mathrm{m}^{-2}\right)$ of pearl millet, respectively. Similar trend was observed in case of sorghum. The maximum number of plants $\left(\mathrm{m}^{-2}\right)$ of sorghum was observed with treatment $I_{2}$ where three number of irrigation was applied which were 79.50 plants. It was followed by $\mathrm{I}_{1}$ (4 number of irrigations) and $\mathrm{I}_{3}$ (2 number irrigations) that showed 71.75 and 78.0 plants $\left(\mathrm{m}^{-2}\right)$ of sorghum, respectively (Fig. $\left.2 \mathrm{~b}\right)$.

\subsection{Number of Leaves per Plants}

The maximum number of leaves per plants of pearl millet was observed with treatment $I_{2}$ where three number of irrigations were applied and that was 15 leaves. It was followed by $\mathrm{I}_{1}$ (4 number of irrigations) and $\mathrm{I}_{3}$ (2 number irrigations) that showed 14.5 and 13 leaves per plant of pearl millet, respectively (Fig.3a). Similar trend was observed in case of sorghum. The data given in Fig. $3 \mathrm{~b}$ showed that the maximum number of leaves per plant of sorghum was observed with treatment $I_{2}$ where three irrigations were applied and that was 12.75 leaves. It was followed by $\mathrm{I}_{1}(4$ number of irrigations) and $\mathrm{I}_{3}$ (2 number irrigations) that showed 12.75 and 11.50 leaves per plant of sorghum, respectively.

\subsection{Fresh Weight per Plant}

The maximum fresh weight per plants of pearl millet was observed with treatment $\mathrm{I}_{2}$ where three number of irrigation was applied which was $185 \mathrm{~g}$ per plant. It was followed by $\mathrm{I}_{1}$ (4 number of irrigations) and $\mathrm{I}_{3}$ (2 number irrigations) that showed 184.25 and $135.25 \mathrm{~g}$ per plant of pearl millet, respectively (Fig. 4a). In case of sorghum, the maximum fresh weight per plant of sorghum was also observed with treatment $\mathrm{I}_{1}$ where four number of irrigation was applied and that was $213.0 \mathrm{~g}$ per plant. It was followed by $\mathrm{I}_{2}$ (3 number of irrigations) and $\mathrm{I}_{3}$ (2 number irrigations) that showed 185.75 and $140.75 \mathrm{~g}$ per plant of sorghum, respectively (Fig. $4 \mathrm{~b}$ ).

\subsection{Leaf Area}

The maximum leaf area $\mathrm{m}^{-2}$ of pearl millet was observed with treatment $I_{2}$ where three number of irrigation was applied that was $202697.75 \mathrm{~cm}^{2} \mathrm{~m}^{-2}$. It was followed by $\mathrm{I}_{1}(4$ number of irrigations) and $\mathrm{I}_{3}$ (2 number irrigations) that showed 150708.11 and $66673.72 \mathrm{~cm}^{2} \mathrm{~m}^{-2}$ of pearl millet, respectively (Fig. 5a). Similarly in case of sorghum, the data presented in Fig. 5b showed that the maximum leaf area of sorghum was observed with treatment $\mathrm{I}_{3}$ where two number of irrigation was applied and that was $178806.85 \mathrm{~cm}^{2} \mathrm{~m}^{-2}$. It was followed by $\mathrm{I}_{2}$ ( 3 number of irrigations) and $\mathrm{I}_{1}$ ( 4 number irrigations) that showed 165066.75 and $146274.49 \mathrm{~cm}^{2} \mathrm{~m}^{-2}$ leaf area of sorghum, respectively.

\subsection{Fresh Leaves Weight $\left(\mathrm{GM}^{-2}\right)$}

It was observed from Fig. 6a that the maximum fresh leaves weight $\left(\mathrm{g} \mathrm{m}^{-2}\right)$ of pearl millet was observed with treatment $\mathrm{I}_{2}$ where three number of irrigation was applied which was $3358.08 \mathrm{~g} \mathrm{~m}^{-2}$. It was followed by treatment $\mathrm{I}_{1}(4$ number of irrigations) and $I_{3}$ (2 number irrigations) that showed 2689.08 and $2275.83 \mathrm{~g} \mathrm{~m}^{-2}$ fresh leaves weight of pearl millet, respectively. Similar trend was observed in case of sorghum. The data given in Fig. $6 \mathrm{~b}$ showed that the maximum fresh leaves weight of sorghum was observed with treatment $I_{2}$ where three number of irrigation was applied and that was $2138.0 \mathrm{~g} \mathrm{~m}^{-2}$. It was followed by $\mathrm{I}_{1}$ (4 number of irrigations) and $\mathrm{I}_{3}$ (2 number irrigations) treatment which showed 2095.0 and $1838.0 \mathrm{~g} \mathrm{~m}^{-2}$ leaves fresh weight of sorghum, respectively.

\subsection{Dry Leaves Weight $\left(\mathrm{GM}^{-2}\right)$}

It was observed from Fig. 7a that the maximum dry leaves weight $\left(\mathrm{g} \mathrm{m}^{-2}\right)$ of pearl millet was observed with treatment $\mathrm{I}_{2}$ where three irrigations were applied and that was $1139.42 \mathrm{~g}$ $\mathrm{m}^{-2}$. It was followed by treatment $\mathrm{I}_{1}$ (4 number of irrigations) 
and $\mathrm{I}_{3}$ (2 number irrigations) that showed 720.72 and 707.37 $\mathrm{g} \mathrm{m}^{-2}$ dry leaves weight of pearl millet, respectively. Similar trend was observed in case of sorghum. The data presented in Fig. $7 \mathrm{~b}$ showed that the maximum dry leaves weight of sorghum was also observed with treatment $\mathrm{I}_{2}$ where three number of irrigations were applied that was $1241.05 \mathrm{~g} \mathrm{~m}^{-2}$. It was followed by treatment $\mathrm{I}_{1}$ (4 number of irrigations) and $\mathrm{I}_{3}$ (2 number irrigations) which showed 1179.38 and $1023.16 \mathrm{~g}$ $\mathrm{m}^{-2}$ leaves dry weight of sorghum, respectively.

\subsection{Water in Leaves at the Time of Harvest}

It was observed from Fig. 8a that the maximum water content in leaves of pearl millet at the time of harvest was observed with treatment $\mathrm{I}_{1}$ where four irrigations were applied which was $65.52 \%$. It was followed by treatment $\mathrm{I}_{2}$ (3 number of irrigations) and $\mathrm{I}_{3}$ (2 number irrigations) that showed 40.17 and $62.34884 \%$ water in leaves of pearl millet, respectively. Similar trend was observed in case of sorghum. The data in Fig. $8 \mathrm{~b}$ showed that the maximum water in leaves of sorghum was observed with treatment $\mathrm{I}_{2}$ where three number of irrigations were applied that was $58.62348 \%$. It was followed by treatment $\mathrm{I}_{3}$ (2 number irrigations) and $\mathrm{I}_{1}$ (4 number of irrigations) which showed 54.90827 and $54.35615 \%$ water in leaves of sorghum, respectively.

\subsection{Stem Fresh Weight $\left(\mathrm{GM}^{-2}\right)$}

It was observed from Fig. 9a that the maximum stem fresh weight $\left(\mathrm{g} \mathrm{m}^{-2}\right)$ of pearl millet was observed with treatment $\mathrm{I}_{2}$ where three irrigations were applied that was $17103.5 \mathrm{~g} \mathrm{~m}^{-2}$. It was followed by treatment $\mathrm{I}_{1}$ (4 number of irrigations) and $\mathrm{I}_{3}$ (2 number irrigations) that showed 9390 and $7202.75 \mathrm{~g} \mathrm{~m}^{-2}$ fresh stem weight of pearl millet, respectively. Similar trend was observed in case of sorghum. The data given in Fig. 9b showed that the maximum stem fresh weight of sorghum was observed with treatment $I_{2}$ where three number of irrigations were applied that was $11752.74 \mathrm{~g} \mathrm{~m}^{-2}$. It was followed by treatments $\mathrm{I}_{1}$ (4 number of irrigations) and $\mathrm{I}_{3}$ (2 number irrigations) which showed 10760.68 and $8729.65 \mathrm{~g} \mathrm{~m}^{-2}$ stem fresh weight of sorghum, respectively.

\subsection{Stem Dry Weight}

It was observed from Fig. 10a that the maximum dry stem weight $\left(\mathrm{g} \mathrm{m}^{-2}\right)$ of pearl millet was observed with treatment $\mathrm{I}_{2}$ where three number of irrigations were applied that was $4913.983 \mathrm{~g} \mathrm{~m}^{-2}$. It was followed by treatment $\mathrm{I}_{1}$ (4 number of irrigations) and $\mathrm{I}_{3}$ (2 number irrigations) that showed 4004.4 and $3233.78 \mathrm{~g} \mathrm{~m}^{-2}$ dry stem weight of pearl millet, respectively. Similar trend was observed in case of sorghum. The data given in Fig. 10b showed that the maximum dry stem weight of sorghum was observed with treatment $I_{2}$ where three number of irrigation was applied that was $5012.208 \mathrm{~g} \mathrm{~m}^{-2}$. It was followed by treatments $\mathrm{I}_{1}$ (4 number of irrigations) and $\mathrm{I}_{3}$ (2 number irrigations) which showed 3744.905 and $3034.12 \mathrm{~g} \mathrm{~m}^{-2}$ stem dry weight of sorghum, respectively.

\subsection{Water Content in Stem at Harvest}

It was observed from Fig. 11a that the maximum water content in stem of pearl millet was observed with treatment $\mathrm{I}_{2}$ where three number of irrigation were applied that was $68.66 \%$. It was followed by treatment $\mathrm{I}_{1}$ (4 number of irrigations) and $\mathrm{I}_{3}$ (2 number irrigations) that showed 50.75 and $52.43 \%$ water in stem of pearl millet, respectively. Similarly in case of sorghum, the data given in Fig. 11b showed that the maximum water content of sorghum was observed with treatment $\mathrm{I}_{3}$ where two number of irrigation was applied that was $63.40 \%$. It was followed by treatments $\mathrm{I}_{1}$ (4 number of irrigations) and $\mathrm{I}_{2}$ (3 number of irrigations) that showed 56.47 and $55.89 \%$ water content in stem of sorghum, respectively.

\subsection{Fresh Biomass}

It was observed from Fig. 12a that the maximum fresh biomass $\left(\mathrm{Mg} \mathrm{ha}^{-1}\right)$ of pearl millet was observed with treatment $I_{2}$ where three irrigations were applied that was $23.32 \mathrm{Mg} \mathrm{ha}^{-1}$. It was followed by treatments $I_{1}$ (4 number of irrigations) and $\mathrm{I}_{3}(2$ number irrigations) that showed 21.68 and $20.68 \mathrm{Mg} \mathrm{ha}^{-1}$ biomass of pearl millet, respectively. Similar trend was observed in case of sorghum. The data presented in Fig. 12b showed that the maximum biomass of sorghum was observed with treatment $I_{2}$ where three number of irrigation were applied that was $27.96 \mathrm{Mg} \mathrm{ha}^{-1}$. It was followed by treatments $\mathrm{I}_{1}$ (4 number of irrigations) and $\mathrm{I}_{3}(2$ number of irrigations) which showed 22.82 and $21.77 \mathrm{Mg}$ $\mathrm{ha}^{-1}$ fresh biomass of sorghum, respectively.

\subsection{Dry Biomass}

It was observed from Fig.13a that the maximum dry biomass $\left(\mathrm{Mg} \mathrm{ha}^{-1}\right)$ of pearl millet was observed with treatment $\mathrm{I}_{2}$ where three irrigations were applied that was 13.2 $\mathrm{Mg} \mathrm{ha}^{-1}$. It was followed by treatments $\mathrm{I}_{1}$ (4 number of irrigations) and $\mathrm{I}_{3}$ (2 number of irrigations) that showed 12.4 and $11.3 \mathrm{Mg} \mathrm{ha}^{-1}$ dry biomass of pearl millet, respectively. Similar trend was observed in case of sorghum, the data presented in Fig. 13b showed that the maximum biomass of sorghum was observed with treatment $I_{2}$ where three number of irrigation were applied that was $16.55 \mathrm{Mg} \mathrm{ha}^{-1}$. It was followed by treatments $\mathrm{I}_{1}$ (4 number of irrigations) and $\mathrm{I}_{3}(2$ number of irrigations) which showed 14.8 and $13.6 \mathrm{Mg} \mathrm{ha}^{-1}$ dry biomass of sorghum, respectively.

\subsection{Water Use Efficiency}

It was observed from Fig. 14a that the maximum water use efficiency $\left(\mathrm{kg} \mathrm{ha}^{-1} \mathrm{~mm}^{-1}\right)$ of pearl millet was observed with treatment $I_{1}$ where four number of irrigations were applied 
and that was $155.32 \mathrm{~kg} \mathrm{ha}^{-1} \mathrm{~mm}^{-1}$. It was followed by treatments $\mathrm{I}_{2}$ (3 number of irrigations) and $\mathrm{I}_{3}$ ( 2 number of irrigations) that showed 125.18 and $52.28 \mathrm{~kg} \mathrm{ha}^{-1} \mathrm{~mm}^{-1}$ water use efficiency of pearl millet, respectively. Similar trend was observed in case of sorghum. The data presented in Fig. $14 \mathrm{~b}$ showed that the maximum biomass of sorghum was observed with treatment $I_{1}$ where four number of irrigation were applied that was $152.10 \mathrm{~kg} \mathrm{ha}^{-1} \mathrm{~mm}^{-1}$. It was followed by treatments $\mathrm{I}_{2}$ ( 3 number of irrigations) and $\mathrm{I}_{3}$ ( 2 number of irrigations) which showed 124.27 and $72.57 \mathrm{~kg} \mathrm{ha}^{-1} \mathrm{~mm}^{-1}$ water use efficiency of sorghum, respectively.

\subsection{Particle Density before Sowing at Three Depths}

The data in Figure 15.1a, 15.1b showed that particle density of soil at $0-5 \mathrm{~cm}$ depth was observed in range of 2.61-2.63 $\mathrm{Mg} \mathrm{m}^{-3}$ before sowing in plots that was allotted for pearl millet sowing while in plots that were allotted to sorghum, the particle density was in range of $2.64-2.66 \mathrm{Mg}$ $\mathrm{m}^{-3}$ before sowing. Similar trend was observed at 5-10 and 10-15 cm depth before sowing as shown in Figure 15.2a, 15.2b, 15.3a and 15.3b.

\subsection{Particle Density after Harvest at Three Soil Depths}

It was observed from data that the irrigation and crop had non-significant effect on soil particle density after harvest as compared to before harvest. At depth 0-5 cm (Fig. 16.1 a and $16.1 \mathrm{~b}$ ), the maximum particle density was observed with $\mathrm{I}_{3}$ that was $2.64 \mathrm{Mg} \mathrm{m}^{-3}$ after pearl millet harvest and $2.66 \mathrm{Mg}$ $\mathrm{m}^{-3}$ was observed with this treatment after sorghum harvest. The minimum particle density was observed in plots where Treatment $\mathrm{I}_{1}$ was applied in both pearl millet and sorghum. Similar trend was observed at 5-10 and 10-15 cm depth as shown in Figure. 16.2a, 16.2b, 16.3a and 16.3b. Particle density is a static physical property of soil and does not change in such short period of time. Therefore, Particle density before and after harvest of the crop was similar.

\subsection{Bulk Density before Sowing at Three Soil Depths}

Soil bulk density was measured before the sowing of crops from each plot where treatments were applied. Before pearl millet sowing, the bulk density was observed in range of $1.47-1.48 \mathrm{Mg} \mathrm{m}^{-3}$ at $0-5 \mathrm{~cm}^{-3}$ th, $1.52-1.54 \mathrm{Mg} \mathrm{m}^{-3}$ at 5-10 $\mathrm{cm}$ depth and $1.60-1.62 \mathrm{Mg} \mathrm{m}^{-3}$ from plot where treatment $\mathrm{I}_{1}$ (Four number of irrigations), $\mathrm{I}_{2}$ (Three number of irrigations) and $\mathrm{I}_{3}$ (Two number of irrigations) will be applied. Similarly, before sorghum sowing, the bulk density was observed in range $1.47-148 \mathrm{Mg} \mathrm{m}^{-3}$ at $0-5 \mathrm{~cm}$ depth, $1.52-1.54 \mathrm{Mg} \mathrm{m}^{-3}$ at $5-10 \mathrm{~cm}$ depth and $1.60-1.62 \mathrm{Mg} \mathrm{m}^{-3}$ from plot where treatments $\mathrm{I}_{1}$ (Four number of irrigations), $\mathrm{I}_{2}$ (Three number of irrigations) and $I_{3}$ (Two number of irrigations) were applied.

\subsection{Soil Bulk Density at Three Depths after Harvest of Pearl Millet and Sorghum}

It was observed from the data that the crop production and irrigation have minor effect on soil bulk density. The soil bulk density was decreased after harvest as compared to before sowing due to root growth and irrigation which ultimately improved the soil structure. The data in Fig. 18.1a, $18.2 \mathrm{a}$ and $18.3 \mathrm{a}$ showed that the minimum bulk density was observed with treatment $\mathrm{I}_{2}$ (three number of irrigation) that was $1.44,1.49$ and $1.57 \mathrm{Mg} \mathrm{m}^{-3}$ after pearl millet harvest at 0-5, 5-10 and 10-15 cm depth, respectively. Similar trend was observed after sorghum harvest. The values were 1.46, 1.45 and $1.46 \mathrm{Mg} \mathrm{m}^{-3}$ for treatment $\mathrm{I}_{1}$ (Four number of irrigations), $I_{2}$ (three number of irrigation) and $I_{3}$ (Two number of irrigations) at $0-5 \mathrm{~cm}$ depth, $1.55,1.53$ and 1.54 $\mathrm{Mg} \mathrm{m}^{-3}$ for $\mathrm{I}_{1}$ (Four number of irrigations), $\mathrm{I}_{2}$ (three number of irrigation) and $\mathrm{I}_{3}$ (Two number of irrigations) at $5-10 \mathrm{~cm}$ while $1.62,1.61$ and $1.63 \mathrm{Mg} \mathrm{m}^{-3}$ for $\mathrm{I}_{1}$ (Four number of irrigations), $I_{2}$ (three number of irrigation) and $I_{3}$ (Two number of irrigations) were observed.

\subsection{Percent Pore Spaces at Three Soil Depths before Sowing}

Percent of pore spaces was calculated before the sowing of crops from each plot where treatments were applied. Before pearl millet sowing, the percentage pore spaces was observed in range of 43.10-44.06 at $0-5 \mathrm{~cm}$ depth, $42.19-43.16$ at $5-10 \mathrm{~cm}$ depth and $40.41 \%$ at $10-15 \mathrm{~cm}$ depth from plot where treatments will be applied as shown in Figure 4.19.1a, 2a and 3a, respectively. Similarly, before sorghum sowing, the percent pore spaces were observed in range $43.10-44.06$ at $0-5 \mathrm{~cm}$ depth, $41.02-42.20$ at $5-10 \mathrm{~cm}$ depth and $39.32-40.34 \%$ at $10-15 \mathrm{~cm}$ depth from plots where treatments will be applied as shown in Figure19.1b, 19.2b and $19.3 b$.

\subsection{Percent Pore Space at Three Soil Depths after Harvest}

Percent pore spaces were calculated after harvest of crops from each plot where treatments were applied. After harvest of pearl millet, the percent pore spaces was observed in range of 44.46-4539 at 0-5 cm depth, 43.55-44.49 at 5-10 cm depth and $41.32-42.68 \%$ at $10-15 \mathrm{~cm}$ depth from plot where treatments was applied as shown in Figure 20.1a, 20.2a and 2.3a. Similarly, after harvest of sorghum, the percent pore spaces was observed in range $44.64-45.39$ at $0-5 \mathrm{~cm}$ depth, $42.30-43.59$ at $5-10 \mathrm{~cm}$ depth and $40.77-41.53 \%$ at $10-15$ $\mathrm{cm}$ depth from plots where treatments were applied as shown in Figure 20.1b, 20.2b and 20.3b.

There was slight increase in percent pore spaces after harvest as compared to before sowing due to the root activity and root biomass decomposition may have increased the percent pore spaces. The percent pore spaces in treatment $\mathrm{I}_{2}$ where three number of irrigations were applied were 45.38 , 44.49 and $42.67 \%$ after harvest while these were 44.06, 43.16 and $41.28 \%$ at $0-5,5-10$ and $10-15 \mathrm{~cm}$ depth before sowing in pearl millet. The pore spaces were $43.10,42.19$ 
and $40.06 \%$ and $43.41,42.57$ and $40.65 \%$ at $0-5,5-10$ and $10-15 \mathrm{~cm}$ depth in treatment $\mathrm{I}_{1}$ (Four number of irrigations) and $\mathrm{I}_{3}$ (Two number of irrigation), respectively before sowing while the increase in pore spaces was observed as $44.45,43.35$ and 41.31 for $\mathrm{I}_{1}$ (Four number of irrigations) and $44.87,44.03$ and 42.02 for $\mathrm{I}_{3}$ (Two number of irrigation) after harvesting pearl millet at $0-5,5-10$ and $10-15 \mathrm{~cm}$ depths, respectively.

In case of sorghum there was also a slight increase in percent pore spaces and it was $44.06,43.10$ and $43.41 \%$ for $\mathrm{I}_{1}$ (Four number of irrigations), $\mathrm{I}_{2}$ (three number of irrigation) and $\mathrm{I}_{3}$ (Two number of irrigation) before sowing at $0-5 \mathrm{~cm}$ depth while increase in pore spaces was $44.64,45.38$ and $44.87 \%$ for $I_{1}$ (Four number of irrigations), $I_{2}$ (three number of irrigation) and $\mathrm{I}_{3}$ (Two number of irrigation) at the same depth, respectively. For 5-10 depth the percent pore spaces were 41.02, 42.20 and 41.60 for $\mathrm{I}_{1}$ (Four number of irrigations), $I_{2}$ (three number of irrigation) and $I_{3}$ (Two number of irrigation) while increase was 42.30, 43.58 and $42.96 \%$. For depth $10-15 \mathrm{~cm}$ the percent pore spaces were 39.40. 40.34 and $39.32 \%$ before sowing and the increase in pore spaces was $40.77,41.53$ and 40.61 for $\mathrm{I}_{1}$ (Four number of irrigations), $\mathrm{I}_{2}$ (three number of irrigation) and $\mathrm{I}_{3}$ (Two number of irrigation) treatments, respectively.

\subsection{Soil Organic Carbon (SOC) Before Sowing and After Harvest of Fodders under Different Number of Irrigations}

Soil organic carbon as shown in Fig. 21.a indicated the significant increase in the SOC (\%) after the harvest of fodders. It was due to the residues of fodder crops. Pre-sowing 24 samples were collected and their results showed that SOC ranged from 0.31 to $0.38 \%$, while after harvest showed that SOC ranged from 0.37 to $0.47 \%$. Sorghum increased more SOC as compared to pearl millet. The SOC was significantly affected by irrigation. Highest value $(0.49 \%)$ was observed in the plots irrigated with three number of irrigation $\left(\mathrm{I}_{2}\right)$ followed by $\mathrm{I}_{3}$ (Two number of irrigations) and $\mathrm{I}_{1}$ (Four number of irrigations), while $\mathrm{I}_{3}$ (Two number of irrigations) and $\mathrm{I}_{2}$ (Three number of irrigations) difference were non-significant with each other but $\mathrm{I}_{1}$ (Four number of irrigations) was significant with respect to $\mathrm{I}_{2}$ (Three number of irrigations) and $\mathrm{I}_{3}$ (four number of irrigations). Pre-sowing analysis of soil organic carbon samples showed decrease in SOC at depth 5-10 cm and further below it. Pre-sowing SOC ranged from 0.29 to $0.35 \%$. Fodder production slightly increased the SOC as shown in the Fig. 21.b and after harvest analysis showed that SOC ranged from 0.31 to $0.39 \%$ which was 6 to $11 \%$ higher than the pre-sowing. Irrigation non-significantly affected the SOC but highest value $(0.38 \%)$ was observed where three number of irrigation $\left(\mathrm{I}_{2}\right)$ was applied followed by $\mathrm{I}_{3}$ (Two number of irrigations) and $I_{1}$ (Four number of irrigations). The SOC did not differ much due to the fodder production at depth 5-10 cm as shown in Fig. 21.c. But irrigation showed significant affect on SOC at both depths, $\mathrm{I}_{2}$ (Three number of irrigations) and $\mathrm{I}_{3}$ (Two number of irrigations) were non-significant while $\mathrm{I}_{1}$ (Four number of irrigations) effect was significan

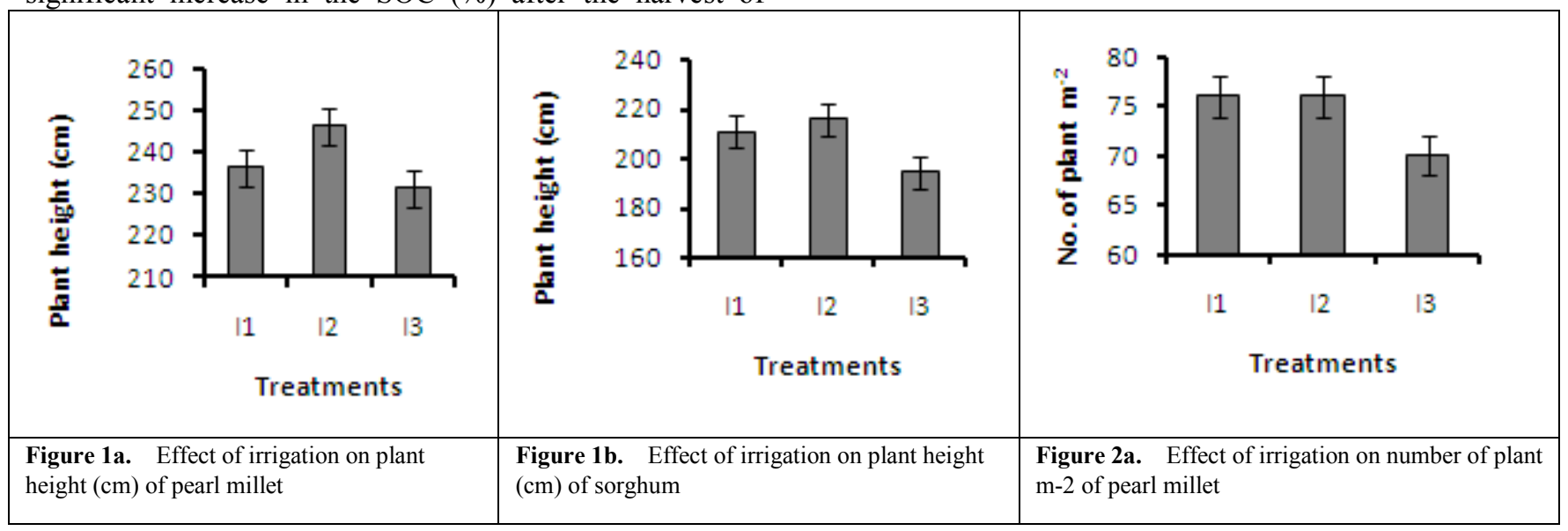




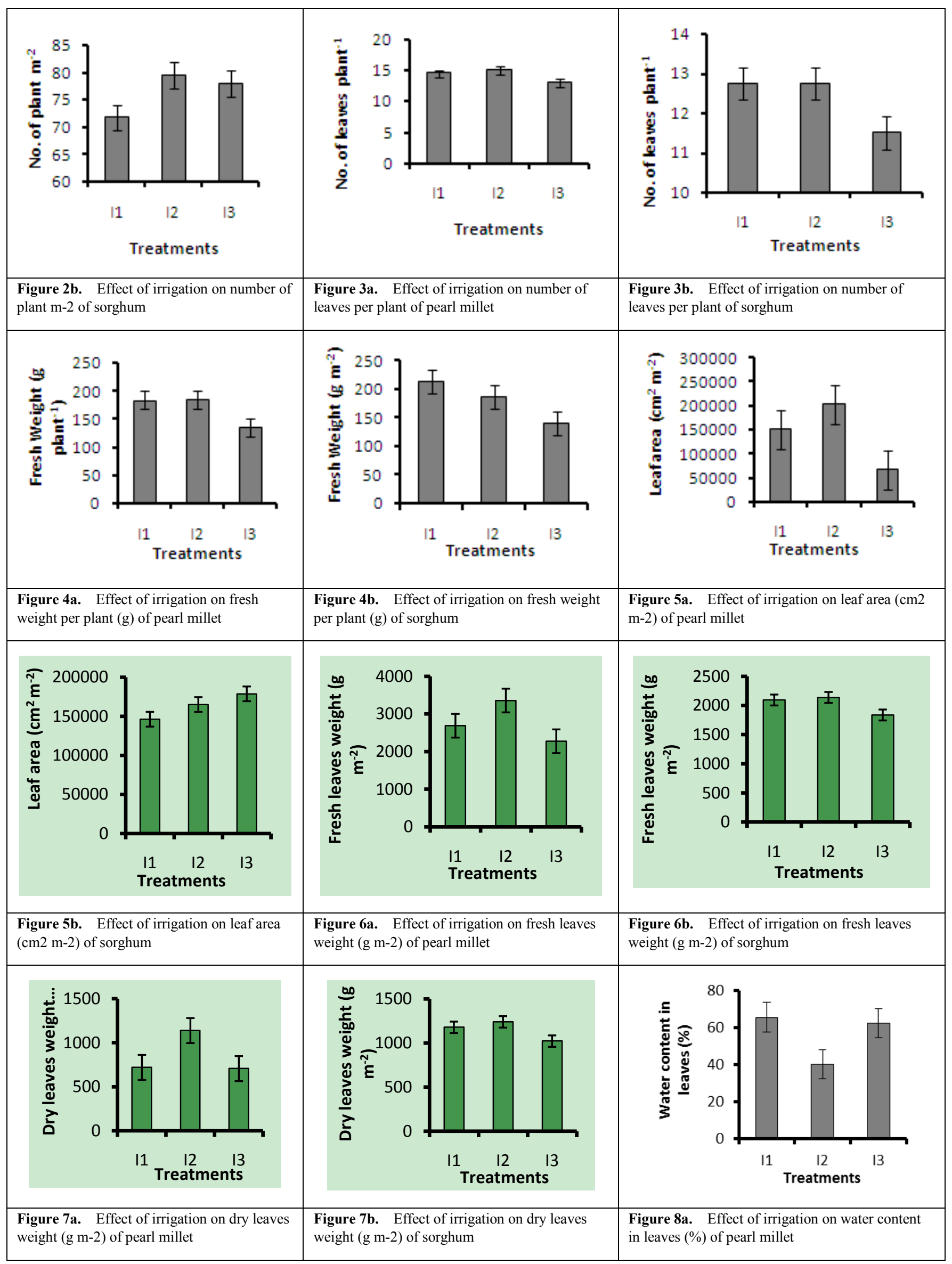




\begin{tabular}{|c|c|c|}
\hline 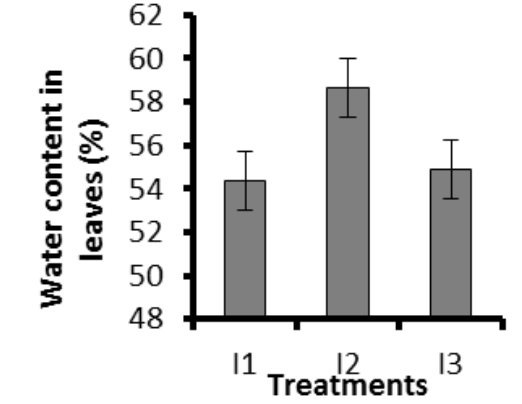 & 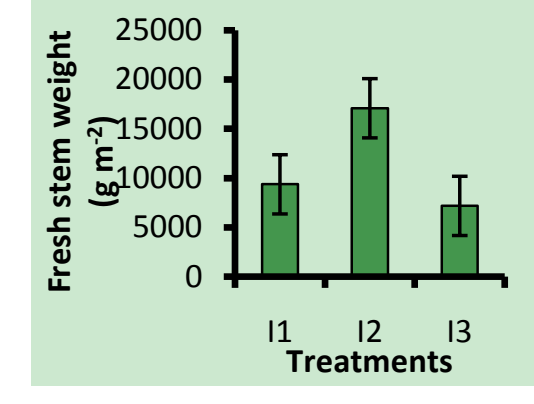 & 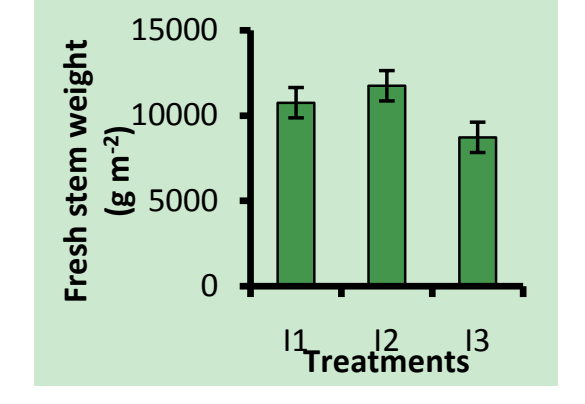 \\
\hline $\begin{array}{l}\text { Figure 8b. Effect of irrigation on water } \\
\text { content in leaves }(\%) \text { of sorghum }\end{array}$ & $\begin{array}{l}\text { Figure 9a. Effect of irrigation on fresh stem } \\
\text { weight }(\mathrm{g} \mathrm{m}-2) \text { of pearl millet }\end{array}$ & $\begin{array}{l}\text { Figure 9b. Effect of irrigation on fresh stem } \\
\text { weight }(\mathrm{g} \mathrm{m}-2) \text { of sorghum }\end{array}$ \\
\hline 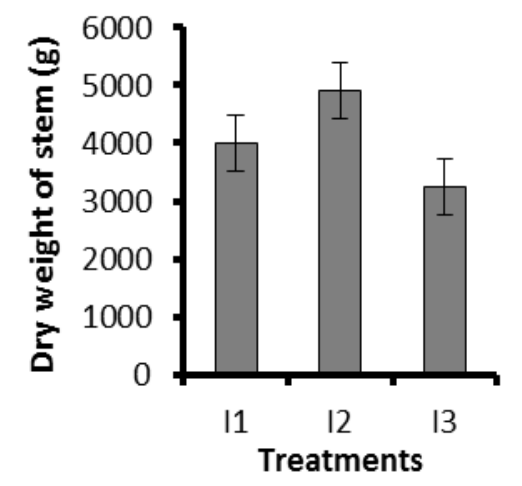 & & 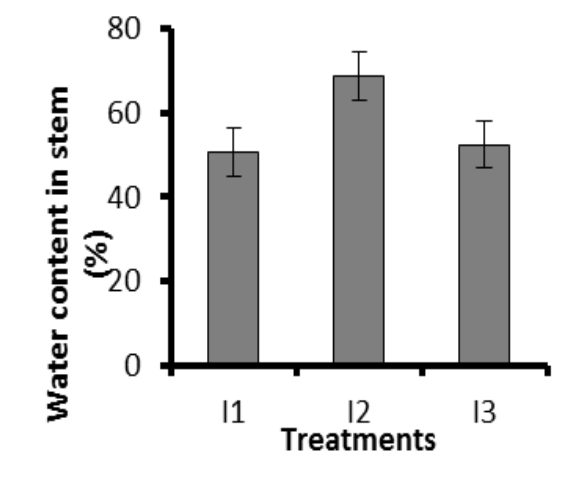 \\
\hline $\begin{array}{l}\text { Figure 10a. Effect of irrigation on dry stem } \\
\text { weight }(\mathrm{g} \mathrm{m}-2) \text { of pearl millet }\end{array}$ & $\begin{array}{l}\text { Figure 10b. Effect of irrigation on dry stem } \\
\text { weight }(\mathrm{g} \mathrm{m}-2) \text { of sorghum }\end{array}$ & $\begin{array}{l}\text { Figure 11a. Effect of irrigation on water content } \\
\text { in stem (\%) of pearl millet }\end{array}$ \\
\hline 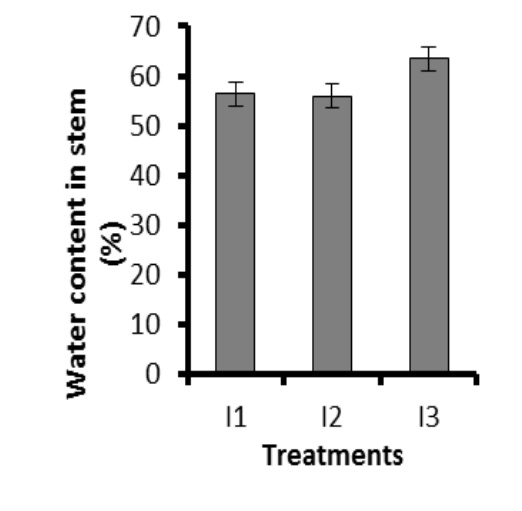 & 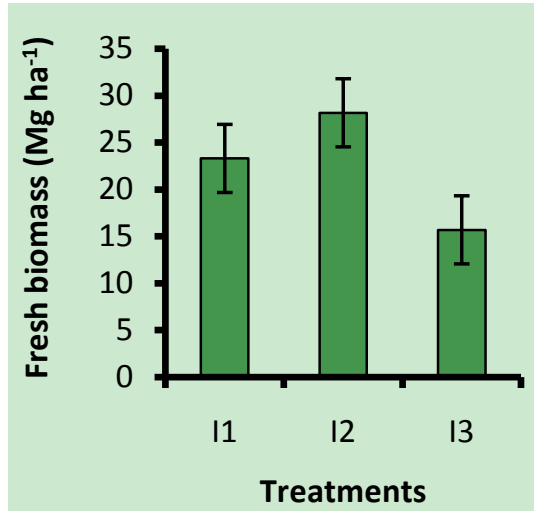 & 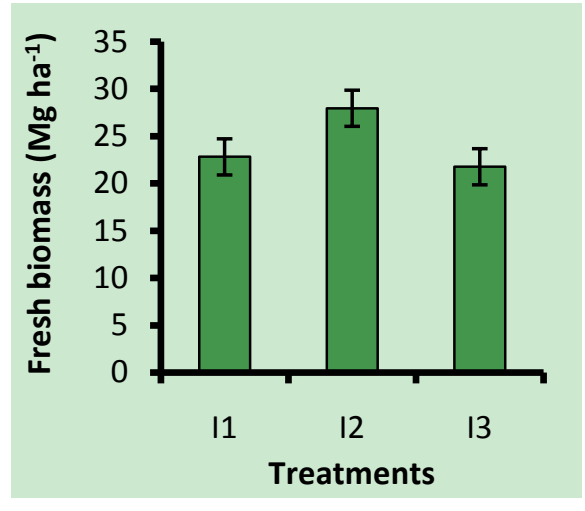 \\
\hline $\begin{array}{l}\text { Figure 11b. Effect of irrigation on water } \\
\text { content in stem (\%) of sorghum }\end{array}$ & $\begin{array}{l}\text { Figure 12a. Effect of irrigation on fresh } \\
\text { biomass (Mg ha-1) of pearl millet }\end{array}$ & $\begin{array}{ll}\text { Figure 12b. } & \begin{array}{l}\text { Effect of irrigation on fresh biomass } \\
\text { (Mg ha-1) of sorghum }\end{array}\end{array}$ \\
\hline
\end{tabular}




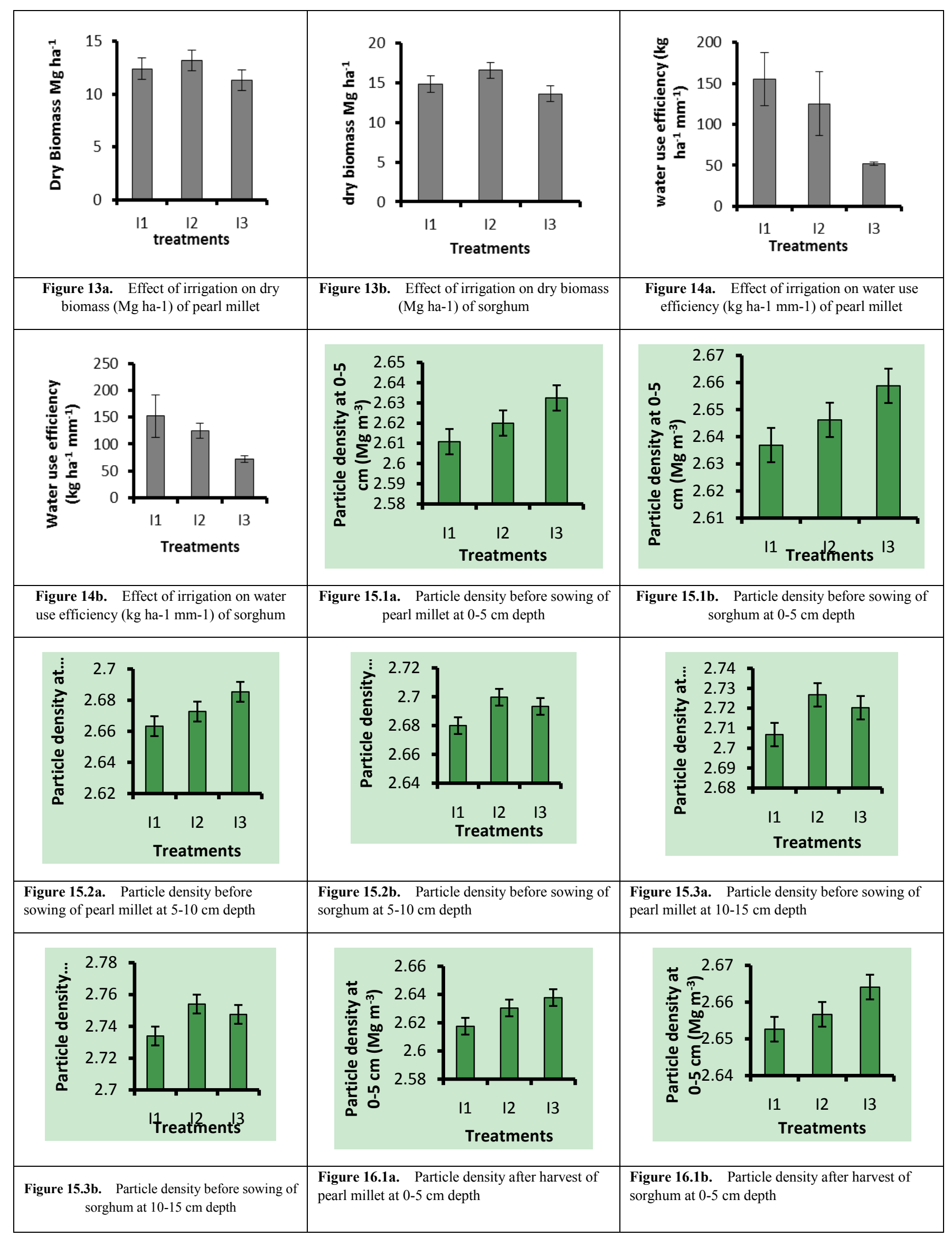




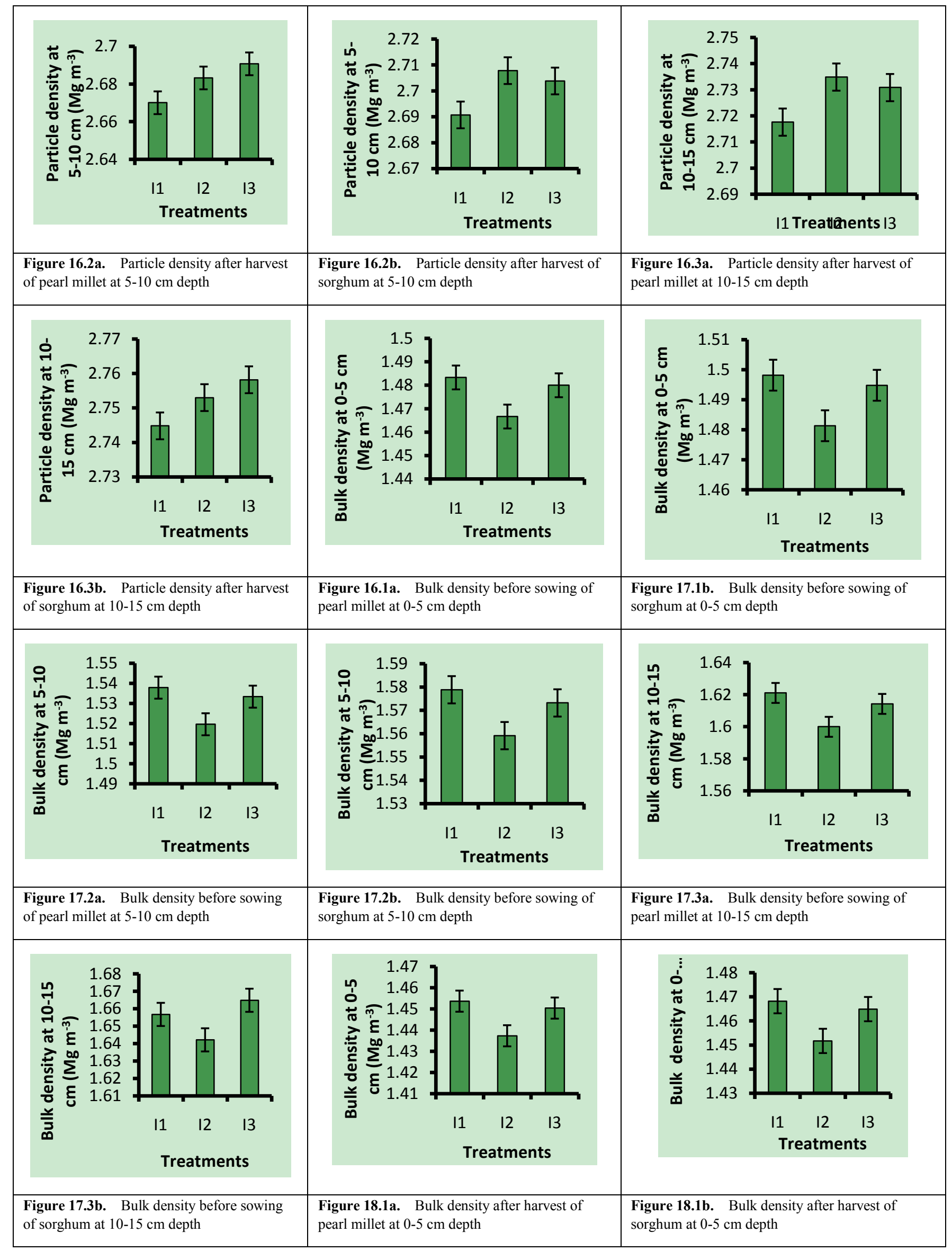




\begin{tabular}{|c|c|c|}
\hline 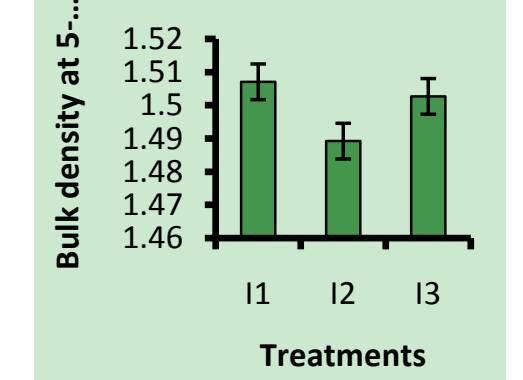 & 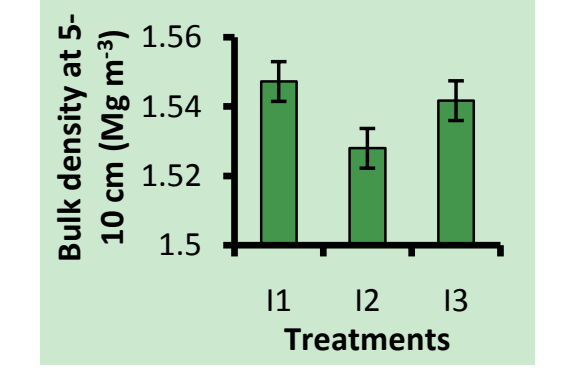 & 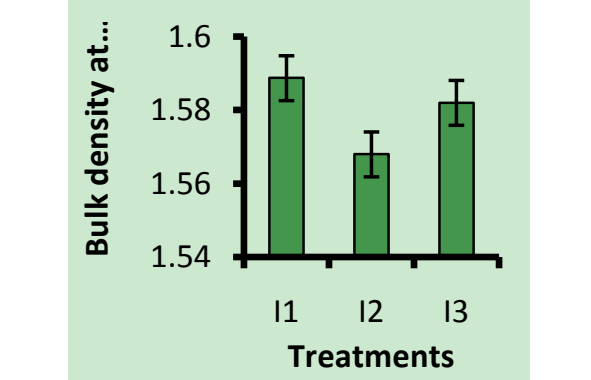 \\
\hline $\begin{array}{l}\text { Figure 18.2a Bulk density after harvest of pearl } \\
\text { millet at } 5-10 \mathrm{~cm} \text { depth }\end{array}$ & $\begin{array}{l}\text { Figure } 18.2 \mathrm{~b} \text { Bulk density after harvest of sorghum } \\
\text { at } 5-10 \mathrm{~cm} \text { depth }\end{array}$ & $\begin{array}{l}\text { Figure 18.3a Bulk density after harvest of pearl millet } \\
\text { at } 10-15 \mathrm{~cm} \text { depth }\end{array}$ \\
\hline 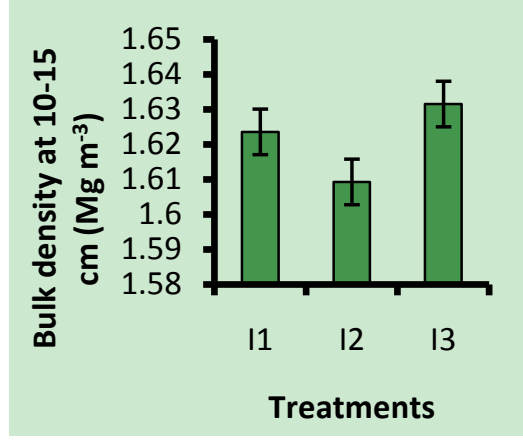 & 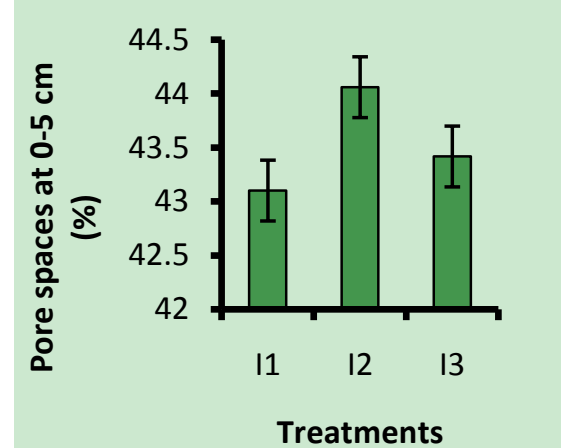 & 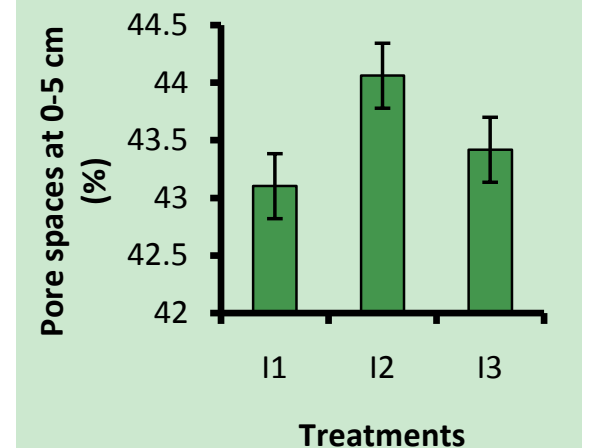 \\
\hline $\begin{array}{l}\text { Figure 18.3b. Bulk density after harvest of } \\
\text { sorghum at } 10-15 \mathrm{~cm} \text { depth }\end{array}$ & $\begin{array}{l}\text { Figure 19.1a. Percent pore spaces at } 0-5 \mathrm{~cm} \\
\text { depth before sowing of pearl millet }\end{array}$ & $\begin{array}{l}\text { Figure 19.1b. Percent pore spaces at } 0-5 \mathrm{~cm} \\
\text { depth before sowing of sorghum }\end{array}$ \\
\hline 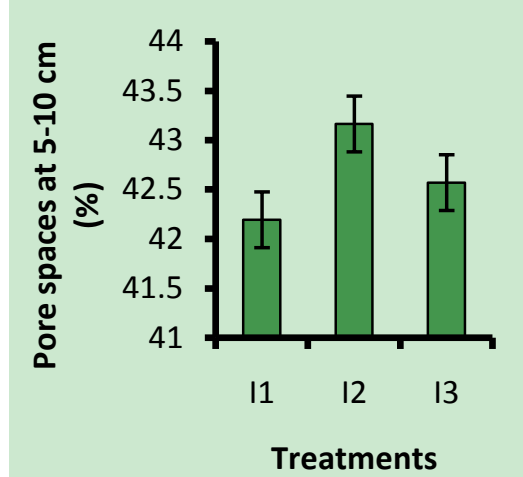 & 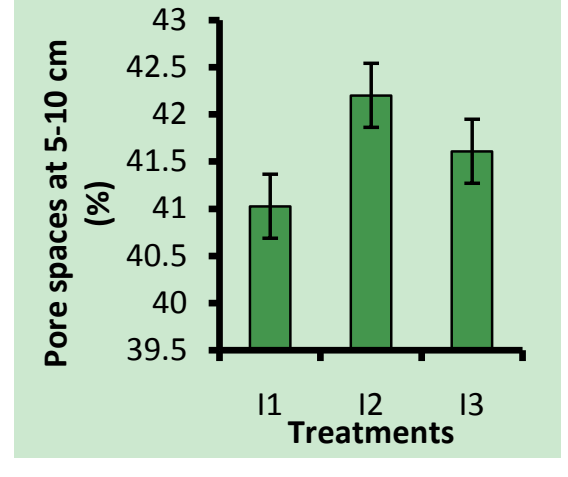 & 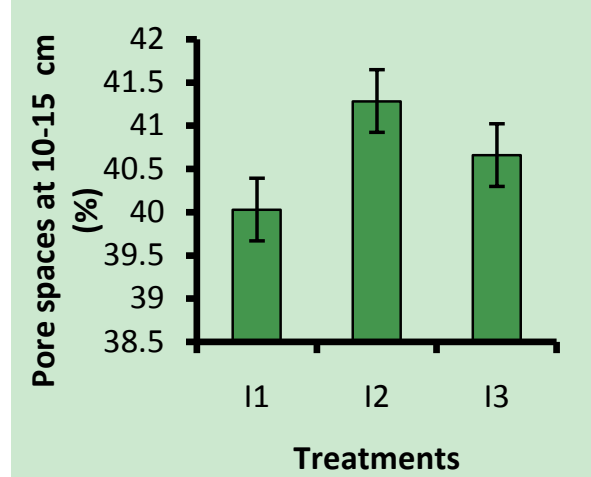 \\
\hline $\begin{array}{l}\text { Figure 19.2a. Percent pore spaces at } 5-10 \\
\text { cm depth before sowing of pearl millet }\end{array}$ & $\begin{array}{l}\text { Figure 19.2b. Percent pore spaces at } 5-10 \mathrm{~cm} \\
\text { depth before sowing of sorghum }\end{array}$ & $\begin{array}{l}\text { Figure 19.3a. Percent pore spaces at } 10-15 \mathrm{~cm} \\
\text { depth before sowing of pearl millet }\end{array}$ \\
\hline
\end{tabular}




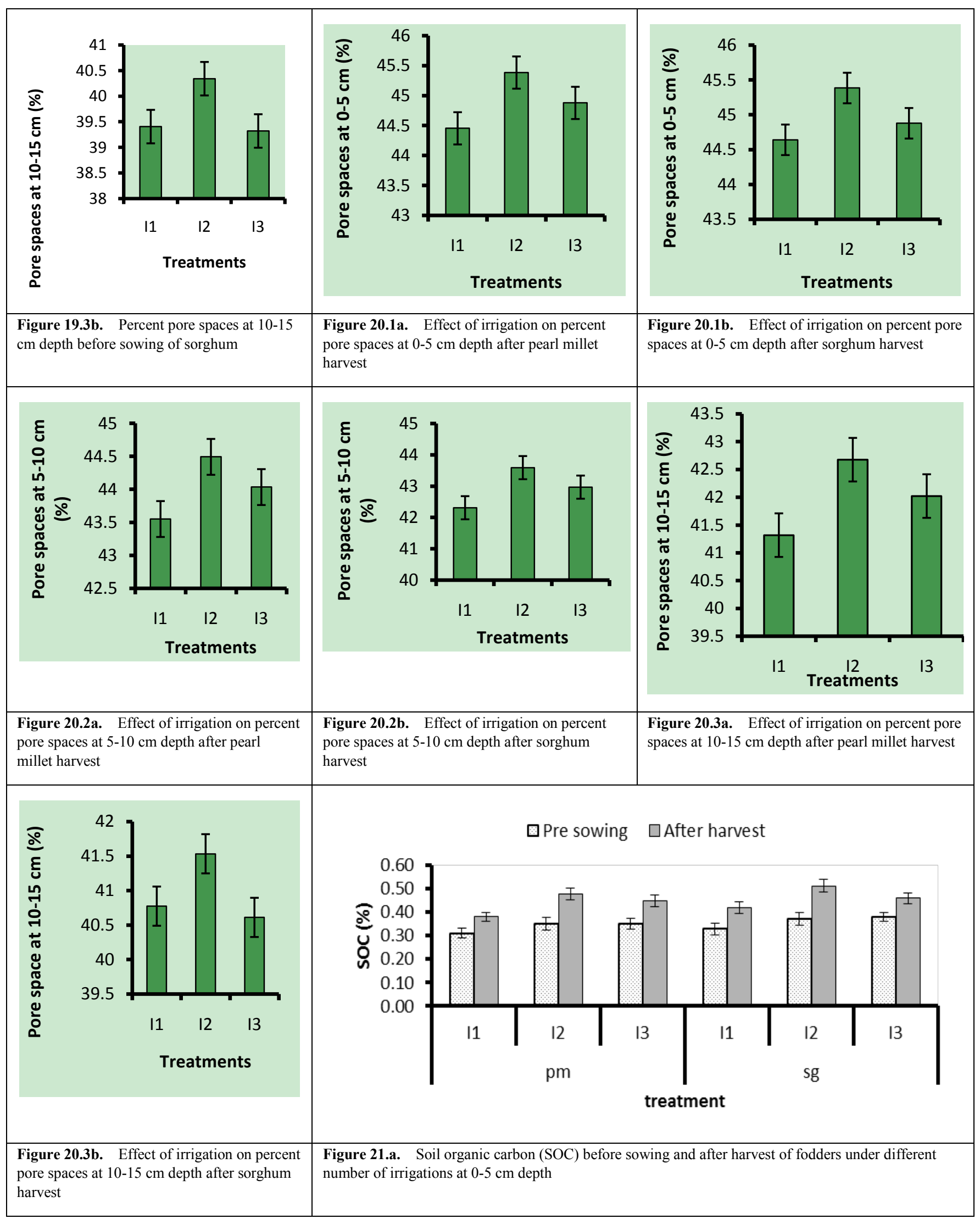




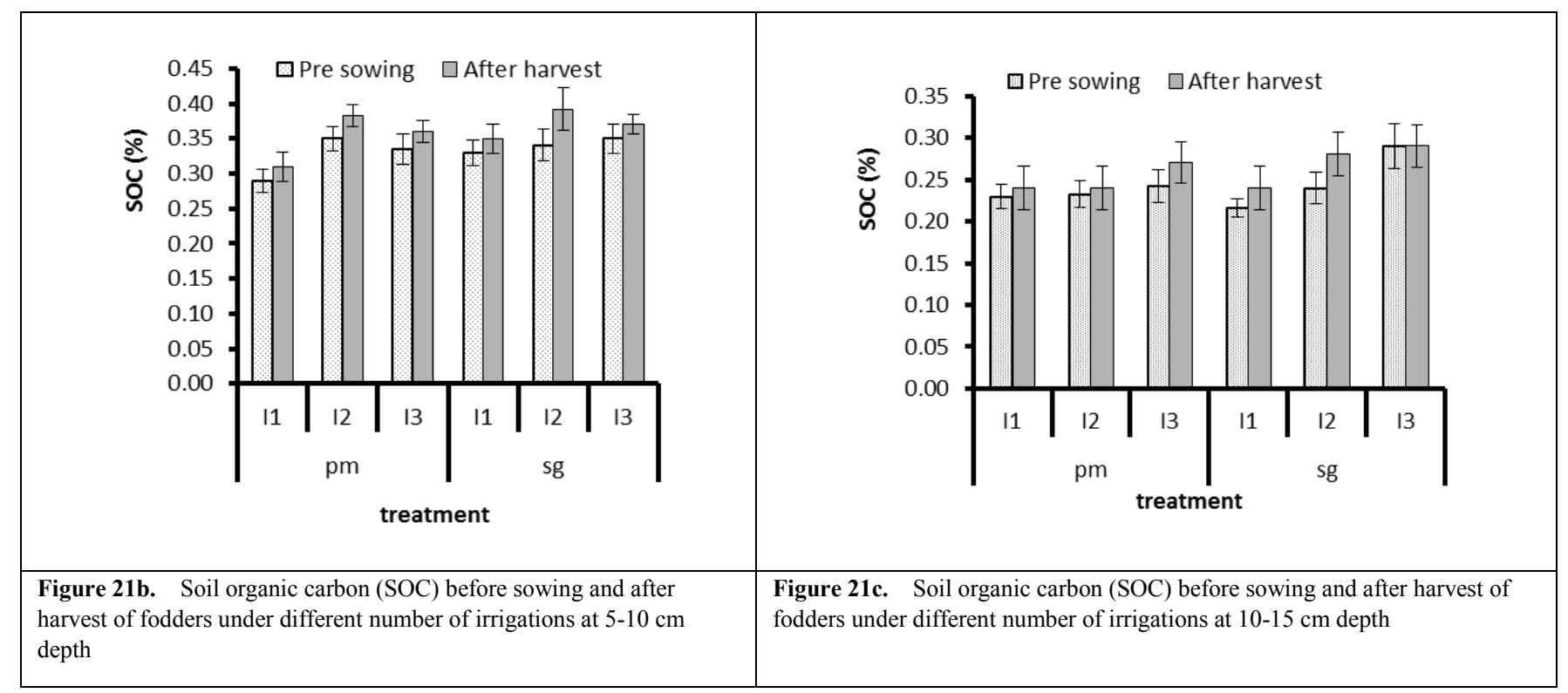

\section{Discussion}

Fodders are the very vital resource for the development of agricultural economy of the poor countries for the purpose of livestock raising. Our results are in line with those of Abdel-Motagalty [35] who observed maximum plant height $(214 \mathrm{~cm})$, head length $(24.99 \mathrm{~cm})$, head weight $(87.16 \mathrm{~g})$, grain yield $\left(55.45 \mathrm{~g} \mathrm{head}^{-1}\right)$, seed index $(32.91 \mathrm{~g})$, grain yield $\left(7.59 \mathrm{~kg} \mathrm{plot}^{-1}\right)$ and straw yield $\left(24.27 \mathrm{~kg} \mathrm{plot}^{-1}\right)$ in the plots irrigated with $\mathrm{I}_{2}$ followed by $\mathrm{I}_{1}$ and $\mathrm{I}_{3}$. Similarly, Singh and Singh [36] findings also supported our results.

Our results are in line with those of Al-Suhaibani [37] whose evaluate the effect of irrigation and plant densities on forage and grain yield of pearl millet (Pennisetum glaucum L.) as well as on the quality of forage. Their results showed a quick increase in forage yield when irrigation was applied at the interval of 5 days. Plant densities also imposed significant effects on growth parameters. Highest leaf area index was recorded in lowest plant density but high plant density enhanced fresh and dry weight of pearl millet.

The results are in line with Saifullah et al. [38] who reported that maximum plant height $(230 \mathrm{~cm})$, green fodder yield $71.9 \mathrm{t} \mathrm{ha}^{-1}$ and dry fodder yield $\left(18.2 \mathrm{t} \mathrm{ha}^{-1}\right)$ were obtained from the plots where double irrigation was applied in comparison with the single irrigation.

The results are similar to those of Singh and Singh [36] who reported that there was no difference in dry matter yield (DMY) between all three crops under wet condition $\left(\mathrm{S}_{\mathrm{o}}\right)$, but sorghum out yielded maize at all three levels of water scarcity $\left(\mathrm{S}_{1}, \mathrm{~S}_{2}, \mathrm{~S}_{3}\right)$, sorghum was also superior to pearl millet under moderate water stress $\left(\mathrm{S}_{1}, \mathrm{~S}_{2}\right)$, while pearl millet showed greater water use efficiency (WUE) than sorghum under stress condition $\left(\mathrm{S}_{3}\right)$. Conclusion of this study shows that sorghum should be used as a fodder crop under water stress and hot dry climate of semi-arid regimes..

Our results also showed similarity with the findings of
Saeed and Nadi [39] who studied the effect of three different irrigation treatments on the yield of forage sorghum (Sorghum bicolor L.). Results showed that leaf area indices and plant heights were significantly higher where frequent irrigation was applied as compared to less frequent irrigation plots. Water use efficiency (WUE) was highest in light irrigated plots as compared to moderate or heavy irrigation. It was concluded that WUE and DMY of fodder in semi-arid regions can be enhanced by applying light irrigation with short intervals.

These findings were supported by those of Sameni and Soleimani [40] who observed higher SOC in the upper layer of the soil than the lower one. Bakht et al. [41] reported that soil organic carbon (SOC) increased due to the residues of the crops.

\section{REFERENCES}

[1] J. A. Bhatti. Improved fodder production in Punjab. Livestock and Dairy Magazine, Vol.23, 38-39, 2001

[2] M. Q. Bilal, M. Abdullah, M. Lateef. Effect of mott dwarf elephant grass (Pennisetum purpureum L.) silage on dry matter intake, milk production and digestibility and rumen characteristics in Nili-Ravi buffaloes. In: Proc. 54th Annual Reciprocal Meat Conference, Indianapolis IN, USA. 2001.

[3] S. H. Hingra, J.B. Davis, M.J.A. Akhtar. Fodder Production Pak/88/072. Small Holder Dairy Development in Punjab. Food and Agriculture Organization of United Nations, Rome. Italy. 1995.

[4] I. S. Khairwal, S.K. Yadav, K.N. Rai, H.D. Upadhyaya, D. Kachhawa, B. Nirwan, R. Bhattacharjee, B.S. Rajpurohit, C.J. Dangaria, Srikant. Evaluation and identification of promising pearl millet germplasm for grain and fodder traits. Journal of Agrcultural Research, Vol.5, No.1, 1-6, 2007. 
[5] S. A. Rao, M.H. Mengesh, P.K. Sibale, C.R. Reddy. Collection and evaluation of pearl millet germplasm from Malavi. Economic Botany, Vol.40, 27-37, 1986.

[6] S. C. Sharma, V.P. Gupta, D.R. Satija. Genetic analysis in inbred-varietal diallel cross vis-à-vis diallel crosses with either inbreds or varieties for green fodder yield and its components in pearl millet, Journal of Research, Vol.24, No.2, 261-263, 1987.

[7] B. H. Choi, K.Y. Park, R.K. Park. Productivity of pearl millet (Pennisetum americanum L.) in Korea. Res. Rep. Rural. Dev. Administration, Upland and Industrial Crops. Korea Republic. 1988.

[8] M. Byrejowda Performance of fodder bajra genotype under rainfed conditions. Current Research, India. 1990

[9] M. Akmal, M. Naeem, S. Nasim, A. Shakoor. Performance of different pearl millet genotypes under rain fed conditions, Journal of Agricultural Research, Vol.30, 8-53, 1992.

[10] M. Naeem, M.S.M. Chohan, A.H. Khan, S. Salah-ud-Din. Study of green fodder yield potential and its components of different pearl millet varieties under irrigated condition of Faisalabad, Asian Journal of Plant Sciences Vol.2, 74-76, 1994.

[11] Anonymous. Economic Survey of Pakistan. Finance Division, Government of Pakistan, Economic Advisors Wing. Islamabad, Pakistan, 2006.

[12] B. M. Sani, K.O. Oluwasemire. Effect of irrigation and plant density on the growth, yield and water use efficiency of early maize in the Nigerian Savanna., Journal of Agriculture \& Biological Sciences, Vol.3, No.2, 33-40, 2008.

[13] N. Hunt, R. Gilkes. Farm Monitoring Handbook. The University of Western Australia, Nedlands, Australia.

[14] I. Hakansson, R.C. Reeder. Subsoil compaction by vehicles with high axle load-Extent, persistence and crop response, Soil Tillage Research, Vol.29, 277-304, 1994.

[15] M. Oussible, P.K. Crookston, W.E. Larson. Subsurface compaction reduces the root and shoots growth and grain yield of wheat, Agronomy Journal, Vol.84, 34-38, 1992.

[16] B. Kayombo, R. Lal. Effect of soil compaction by rolling on soil structure and development of maize in no till and discing system on a tropical alfisol. Soil Tillage Research, Vol.7, $117-134,1986$.

[17] H. M. Taylor H.R. Gardner. Penetration of cotton seedling tap roots as influenced by bulk density, moisture content and strength of soil. Soil Science, Vol.96, No.3, 153-156, 1963.

[18] N. V. Duivenbooden, M. Pala, C. Studer, C.L. Bielders, D.J. Beukes. Cropping systems and complementarity in dry land agriculture to increase water use efficiency. Netherlands Journal of Agricultural Sciences Vol.48, 213-236, 2000.

[19] E. Daly, A. Porporto, I. Rodriguez-Iturbe. Coupled dynamics of photosynthesis, transpiration and soil water balance: Part II: Stochastic analysis and ecohydrological significance, Journal of Hydrometeorology, Vol.5, 559-566, 2004.

[20] Y. S. Li, M.B. Huang. Pasture yield and soil water depletion of continuous growing alfalfa in the Loess Plateau of China. Agriculture, Ecosystems and Environment, Vol.124, 24-32, 2008.
[21] S. Aishah, H.A.R. Saberi, R.A. Halim, A.R. Zaharah. Yield responses of forage sorghums to salinity and irrigation frequency. African Journal of Biotechnology, Vol.10, 4114-4120, 2011.

[22] G. Oron. Recycling drainage water in San-Joaquin Valley, California, Journal of Irrigation and Drainage Engineering, Vol.119, No.2, 265-285, 1993.

[23] R. Munns. Comparative physiology of salt and water stress. Plant Cell Environment, Vol.25, 239-250, 2002.

[24] H. Athar, M. Ashraf. Photosynthesis under drought stress. In: Hand Book Photosynthesis. 2nd Ed. M. Pessarakli (ed.). CRC Press, New York, USA. 2005.

[25] N. P. Saxena. The role of potassium in drought tolerance. International Potash, 1985.

[26] S. Umar, Moinuddin. Genotypic differences in yield and quality of groundnut as affected by potassium nutrition under erratic rainfall conditions. Journal of Plant Nutrition. Vol.25, 1549-1562, 2002.

[27] E. I. Ekwue, Organic matter effects on soil strength properties. Soil Tillage Research, Vol.16, 289-297, 1990.

[28] D. H. Min, K.R. Islam, L.R. Vough and R.R. Weil. Dairy manure effects on soil quality properties and carbon sequestration in alfalfa-orchard-grass systems. Communication of Soil Science and Plant Analysis, Vol.34, 781-799, 2003.

[29] G. J. Bouyoucos, Hydrometer method improved for making particles size analysis of soils. Agronomy Journal, Vol.54, 464-465, 1962.

[30] G. R. Blake, K.H. Hartge. Bulk density. In: Klute, A. (ed.) Methods of Soil Analysis. Part 1. 2nd Ed. Agronomy Monograph. Modison. USA. 1986.

[31] J. L. Bradford, Penetrability. In A. Klute (ed.) Methods of Soil Analysis Part 1. ${ }^{\text {nd }}$ Ed. Agron. Mono, Madison, USA. 1986.

[32] N. J. McKenzie, D.J. Jacquier, R.F. Isbell and K.L. Brown. Australian Soils and Landscapes. An Illustrated Compendium. CSIRO Publishing. Collingwood, Victoria, Australia. 2004.

[33] R. W. Miller, R.L. Donahue. Soils, An introduction to Soils and Plant Growth. Prentice-Hall Inc., Englewood Cliffs, USA. 1990

[34] R. G. D. Steel, J.H. Torrie, D.A. Dicky. Principles and Procedures of Statistics: A Biometrical Approach. 3rd Ed. McGraw Hill Book International Co. Singapore. 1997.

[35] F.M.F. Abdel-Motagally. Evaluation of water use efficiency under different water regimes in grain sorghum (Sorghum bicolor L. Monech). World Journal of Agricultural Science, Vol.6, 499-505, 2010

[36] B.R. Singh and D.P. Singh. Agronomic and physiological responses of sorghum, maize and pearl millet to irrigation. Field Crops Research, Vol. 42, 57-67, 1995.

[37] N.A. Al-Suhaibani. Better forage and grain yield quality of pearl millet (Pennisetum glaucum L.) under different irrigation water supplies and plant densities. Journal of World Applied Science, Vo.15, 1136-1143, 2011.

[38] A.J. Saifullah, F. Munsif, M. Arif, H. Khan, K. Ali, M. Waqas 
and A. Ali. Performance of millet varieties under different irrigation levels. Sarhad Journal of Agriculture, Vo. 27, 281-284, 2011.

[39] M.A. Saeed and A.H. Nadi. Forage sorghum yield and water use efficiency under variable irrigation. Irrigation Science, Vol.18, 67-71, 1998.

[40] A.M. Sameni and R. Soleimani. Effect of salinity and some chemical properties of the under and intercanopy soils on range plants in a dry region of Southern Iran. Communication in Soil Science and Plant Analysis, Vol.38, 15-33, 2007.

[41] J. Bakht, M. Shafi, M.T. Jan and Z. Shah. Influence of crop residues management, cropping system and $\mathrm{N}$ fertilizer on soil $\mathrm{N}$ and $\mathrm{C}$ dynamics and sustainable wheat production. Soil and Tillage Research, Vol. 104, 233-240, 2009. 